\title{
Altering the sphingolipid acyl chain composition prevents LPS/GLN-mediated hepatic failure in mice by disrupting TNFR1 internalization
}

\author{
M Ali $^{1}$, J Fritsch ${ }^{2}$, H Zigdon ${ }^{1}$, Y Pewzner-Jung ${ }^{1}$, S Schütze ${ }^{2}$ and AH Futerman ${ }^{\star, 1}$
}

The involvement of ceramide in death receptor-mediated apoptosis has been widely examined with most studies focusing on the role of ceramide generated from sphingomyelin hydrolysis. We now analyze the effect of the ceramide acyl chain length by studying tumor necrosis factor $\alpha$ receptor-1 (TNFR1)-mediated apoptosis in a ceramide synthase 2 (CerS2) null mouse, which cannot synthesize very-long acyl chain ceramides. CerS2 null mice were resistant to lipopolysaccharide/galactosaminemediated fulminant hepatic failure even though TNF $\alpha$ secretion from macrophages was unaffected. Cultured hepatocytes were also insensitive to TNF $\alpha$-mediated apoptosis. In addition, in both liver and in hepatocytes, caspase activities were not elevated, consistent with inhibition of TNFR1 pro-apoptotic signaling. In contrast, Fas receptor activation resulted in the death of CerS2 null mice. Caspase activation was blocked because of the inability of CerS2 null mice to internalize the TNFR1; whereas Fc-TNF $\alpha$ was internalized to a perinuclear region in hepatocytes from wild-type mice, no internalization was detected in CerS2 null mice. Our results indicate that altering the acyl chain composition of sphingolipids inhibits TNFR1 internalization and inhibits selective pro-apoptotic downstream signaling for apoptosis.

Cell Death and Disease (2013) 4, e929; doi:10.1038/cddis.2013.451; published online 21 November 2013

Subject Category: Experimental Medicine

The role of the tumor necrosis factor $\alpha$ receptor-1 (TNFR1) in apoptosis has been widely studied. ${ }^{1,2}$ TNFR1 engagement results in recruitment of the TNFR1 complex I proteins tumor necrosis factor $\alpha$ receptor-associated via death domain (TRADD), tumor necrosis factor $\alpha$ receptor-interacting protein (RIP1), tumor necrosis factor $\alpha$ receptor-associated factor 2 (TRAF2), IAP and cFLIP, resulting in K63-ubiquitination of RIP1 and activation of the NF $\kappa$ B survival pathway. TNFR1 is internalized, leading to K48-ubiquitination and degradation of RIP1 and TRAF2, cessation of the survival signal, ${ }^{3}$ and activation of TNFR1 pro-apoptotic signaling by recruitment of FADD and caspase 8 to form the 'death-inducing signaling complex' or complex II at intracellular TNF-receptosomes. ${ }^{4-7}$ Internalized TNFR1-containing receptosomes fuse with transGolgi vesicles, forming multivesicular organelles, with subsequent activation of lysosomal enzymes, including acid sphingomyelinase (aSMase) and the pro-apoptotic protease, cathepsin D. ${ }^{4,7,8}$

Ceramide, the backbone of all complex sphingolipids (SLs), is a potent apoptotic mediator that regulates both intrinsic and extrinsic apoptotic triggers and has been implicated in the pathway of tumor necrosis factor $\alpha$ (TNF- $\alpha)$ signaling. ${ }^{9-11}$
Significant evidence has accumulated for a role of both aSMase and neutral (nSMase) sphingomyelinase in TNFR1 signaling. Thus, inhibition of TNFR1-mediated aSMase activation attenuates the apoptotic response, ${ }^{12}$ aSMasedeficient $\left(\mathrm{ASM}^{-/}\right)$mice are highly resistant to TNFR1-mediated apoptosis, ${ }^{13}$ and TNFR1 activation causes accumulation of long (C16-C20) and very-long (C22-C24) acyl chain (VLC) ceramides in hepatocytes, ${ }^{14}$ demonstrating a crucial role for SM-rich membrane domains in TNFR1 complex I signaling. ${ }^{3}$

Much less is known about the role of de novo synthesized ceramides in TNFR1-mediated apoptosis. Recently, we generated a mouse that does not contain any VLC-ceramides and VLC-sphingolipids (SLs) because of ablation of ceramide synthase 2 (CerS2), ${ }^{15,16}$ the enzyme responsible for addition of very-long acyl chains to the sphingoid long chain base. ${ }^{17,18}$ CerS2 null mice display increased rates of hepatocyte death and proliferation, resulting in the formation of multiple hepatic nodules and hepatocellular carcinoma. ${ }^{16}$ In addition, CerS2 null mice display chronic oxidative stress, ${ }^{19}$ as well as hepatic insulin resistance. ${ }^{20}$ Moreover, the mice display major changes in membrane biophysical properties. ${ }^{21}$

\footnotetext{
${ }^{1}$ Department of Biological Chemistry, Weizmann Institute of Science, Rehovot 76100, Israel and ${ }^{2}$ Institute of Immunology, University Hospital of Schleswig-Holstein, Campus Kiel, Kiel, Germany

*Corresponding author: Professor AH Futerman, Department of Biological Chemistry, Weizmann Institute of Science, Rehovot 76100, Israel. Tel: +972 8934 2704; Fax: +972 8934 4112; E-mail: tony.futerman@weizmann.ac.il

Keywords: ceramide; sphingolipids; apoptosis; fulminant hepatic failure; clathrin

Abbreviations: SL, sphingolipid; SM, sphingomyelin; VLC, very-long acyl chain; GLN, D-( + )-galactosamine hydrochloride; aSMase, acid sphingomyelinase; nSMase, neutral sphingomyelinase; TNFR1, tumor necrosis factor $\alpha$ receptor 1; RIP1, tumor necrosis factor $\alpha$ receptor-interacting protein; TRAF2, tumor necrosis factor $\alpha$ receptor-associated factor 2; TRADD, tumor necrosis factor $\alpha$ receptor-associated via death domain; $I_{\kappa} \mathrm{B} \alpha$, inhibitor of $\kappa \mathrm{B} \alpha$; IKK $\alpha / \beta$, inhibitor of $\kappa \mathrm{B}$ kinase; FHF, fulminant hepatic failure; CerS2, ceramide synthase 2; LPS, lipopolysaccharide; WT, wild type; ActD, actinomycin D; BSA, bovine serum albumin; PBST, phosphatebuffered saline containing $0.1 \%$ Tween-20

Received 26.8.13; revised 08.10.13; accepted 10.10.13; Edited by M Federici
} 
In the current study, we examine the role of VLC-ceramides in TNFR1-mediated apoptosis, and demonstrate that CerS2 null mice are completely resistant to fulminant hepatic failure (FHF) because of inhibition of TNFR1 complex II signaling. Our results suggest a critical role for VLC-SLs downstream to TNFR1 complex I signaling and upstream to TNFR1 complex II signaling.

\section{Results}

CerS2 null mice are resistant to FHF. We used a model of FHF that involves injection of lipopolysaccharide (LPS)/D$(+)$-galactosamine hydrochloride (GLN). ${ }^{22}$ Upon injection of a single dose of LPS/GLN, $90 \%$ of wild-type (WT) mice died within approximately $6-8 \mathrm{~h}$ after injection, but CerS2 null mice were completely resistant (Figure 1a). Massive parenchymal damage associated with tissue necrosis and hemorrhage was seen in WT mice, but was totally absent in CerS2 null mice (Figure 1b), consistent with the lack of elevation of the liver enzymes, AST and ALT, in the serum of CerS2 null mice (Figure 1c). Resistance to FHF was not due to impaired $\mathrm{TNF} \alpha$ secretion from macrophages, as $\mathrm{TNF} \alpha$ reached similar levels in both WT and CerS2 null mice 90 min after LPS/GLN injection and remained higher in CerS2 null mice $4 \mathrm{~h}$ after (Figure $1 \mathrm{~d}$ ).

Inhibition of TNFR1-mediated caspase activation in CerS2 null mice. To investigate the effect of TNF $\alpha$ in hepatocytes from WT and CerS2 null mice, cultured hepatocytes were incubated with TNF $\alpha$ and actinomycin D (ActD). ${ }^{23}$ WT hepatocytes died $10-12 \mathrm{~h}$ after treatment but hepatocytes isolated from CerS2 null mice were resistant (Figure 2a). Upon binding of TNF $\alpha$, the TNFR1 trimerizes and activates TNFR1 complex I, which then activates the $\mathrm{NF} \kappa \mathrm{B}$ survival pathway. ${ }^{3,5}$ Subsequently, TNFR1 internalization results in the recruitment of FADD and caspase-8 causing activation of the apoptotic signal through TNFR1-bound complex II.

Hepatocytes isolated from WT and CerS2 null mice were treated with TNF $\alpha /$ ActD resulting in inhibitor of $\kappa$ B kinase $(\mathrm{IKK} \alpha / \beta)$ phosphorylation $5 \mathrm{~min}$ after treatment, which was accompanied by phosphorylation and degradation of inhibitor of $\kappa \mathrm{B} \alpha(1 \kappa \mathrm{B} \alpha)$ to a similar extent both in WT and CerS2 null mice hepatocytes (Figure 2b). Although, CerS2 null mice hepatocytes showed prolonged IKK $\alpha / \beta$ phosphorylation and slower $I_{\kappa} \mathrm{B} \alpha$ degradation, these results indicate that TNFR1 complex I signaling is activated in CerS2 null mice to a similar extent as in WT hepatocytes. In contrast, active cleaved caspase 8 was detected in WT but not in CerS2 null mouse hepatocytes 8-10 h after TNF $\alpha /$ ActD treatment (Figure 2c), demonstrating that CerS2 null hepatocytes are highly resistant to TNF $\alpha /$ ActD-mediated apoptosis because of lack of activation of TNFR1 complex II. Moreover, the degradation of $\mathrm{I} \kappa \mathrm{B} \alpha$ demonstrates that there is no proteasome dysfunction (Figure 2c).

TNFR1 signaling was next examined in LPS/GLN-treated mice by analyzing IKK $\alpha / \beta$ phosphorylation in liver homogenates. IKK $\alpha / \beta$ was phosphorylated within 30-60 min in both WT and CerS2 null mice and was accompanied by a similar extent of $\mathrm{I} \kappa \mathrm{B} \alpha$ phosphorylation and degradation in
WT and CerS2 null mice (Figure 3a). As expected, I $\mathrm{B} \mathrm{B} \alpha$ levels decreased after LPS/GLN injection, but surprisingly, increased $6 \mathrm{~h}$ after injection in CerS2 null mice (Figure 3a). To evaluate the efficacy of transcriptional inhibition, we evaluated levels of $I \kappa B \alpha$ mRNA before and after LPS/GLN treatment, compared with LPS treatment alone. No elevation in $1 \kappa \mathrm{B} \alpha$ mRNA levels was detected after LPS/GLN injection compared with WT and CerS2 null mice injected with LPS only $(0.8 \pm 0.045$ for LPS/GLN versus $4.7 \pm 0.17$ for LPS alone (WT) and $1.3 \pm 0.1$ versus $3.7 \pm 0.5$ (CerS2 null), $n=4$ ) suggesting that the elevation in $\mathrm{I} \kappa \mathrm{B} \alpha$ levels in CerS2 null mice might be due to its elevation in nonparenchymal cells. This is supported by observations in cultured hepatocytes in which $\mathrm{I}_{\kappa} \mathrm{B} \alpha$ levels did not recover even after long times of incubation (10 h) with TNF $\alpha /$ ActD (Figure 2c).

Active p18-caspase 8 was detected $6 \mathrm{~h}$ after LPS/GLN injection in WT mice along with cleavage of caspase 9 and caspase 3, but was barely detectable in CerS2 null mouse liver (Figure 3b). Likewise, caspase activities were not elevated in CerS2 null mouse liver (Figure 3c). Together, these results indicate that pro-apoptotic TNFR1 complex II signaling is inhibited in CerS2 null mice resulting in abrogation of apoptosis in this model of FHF.

In contrast to the inability of LPS/GLN to induce FHF, injection of mice with the Fas agonist antibody, Jo-2, resulted in similar levels of death in both WT and CerS2 null mice (Figure 4a), which was associated with massive parenchymal damage accompanied by hemorrhage and tissue necrosis (Figure 4b) and cleavage of caspase 8 (Figure 4c). These results demonstrate a specific role for VLC-SLs in TNFR1 but not in Fas receptor signaling.

Deficiency of VLC-SLs blocks TNFR1 internalization in hepatocytes. Hepatocytes were next incubated with human IgG1 Fc-conjugated TNF $\alpha$. Hepatocytes were incubated at $4{ }^{\circ} \mathrm{C}$ with $\mathrm{Fc}-\mathrm{TNF} \alpha$ to allow binding of Fc-TNF $\alpha$ to the TNFR1. Subsequent warming to $37^{\circ} \mathrm{C}$ allowed synchronized TNFR1 internalization. Whereas significant levels of Fc-TNF $\alpha$ were internalized in WT hepatocytes, essentially no $\mathrm{Fc}-\mathrm{TNF} \alpha$ was internalized in hepatocytes from CerS2 null mice (Figure 5a), in which distinct cell surface labeling could be detected for as long as $30 \mathrm{~min}$ after warming to $37^{\circ} \mathrm{C}$. The lack of FC-TNF $\alpha$ internalization was confirmed by examining levels of RIP1 and TRAF2, with both significantly decreased in WT hepatocytes at various times after incubation with $\mathrm{TNF} \alpha$, presumably due to degradation, but were unaltered in hepatocytes from CerS2 null mice (Figures $5 \mathrm{~b}$ and $\mathrm{c}$ ). This is consistent with studies showing that inhibition of TNFR1 internalization blocks RIP1 and TRAF2 degradation. ${ }^{24}$ Similar results were obtained in LPS/GLN-treated mice in which intracellular TNFR1 labeling could be clearly detected in WT but not in CerS2 null mouse liver where labeling was observed on the cell surface (Figure 6a). Similar results were obtained after mice were injected with concanavilin $A$, which directly activates $T$ cells that infiltrate into the liver, and as a result causes secretion of cytokines including TNF $\alpha$ and activation of TNFR1 on hepatocytes. TNFR1 was internalized in WT but not in CerS2 null mouse liver (Figure 6b). No changes 
a

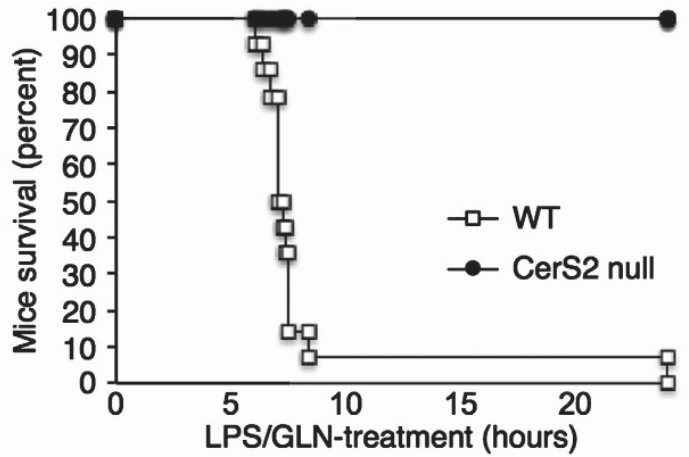

b Control

LPS/GLN
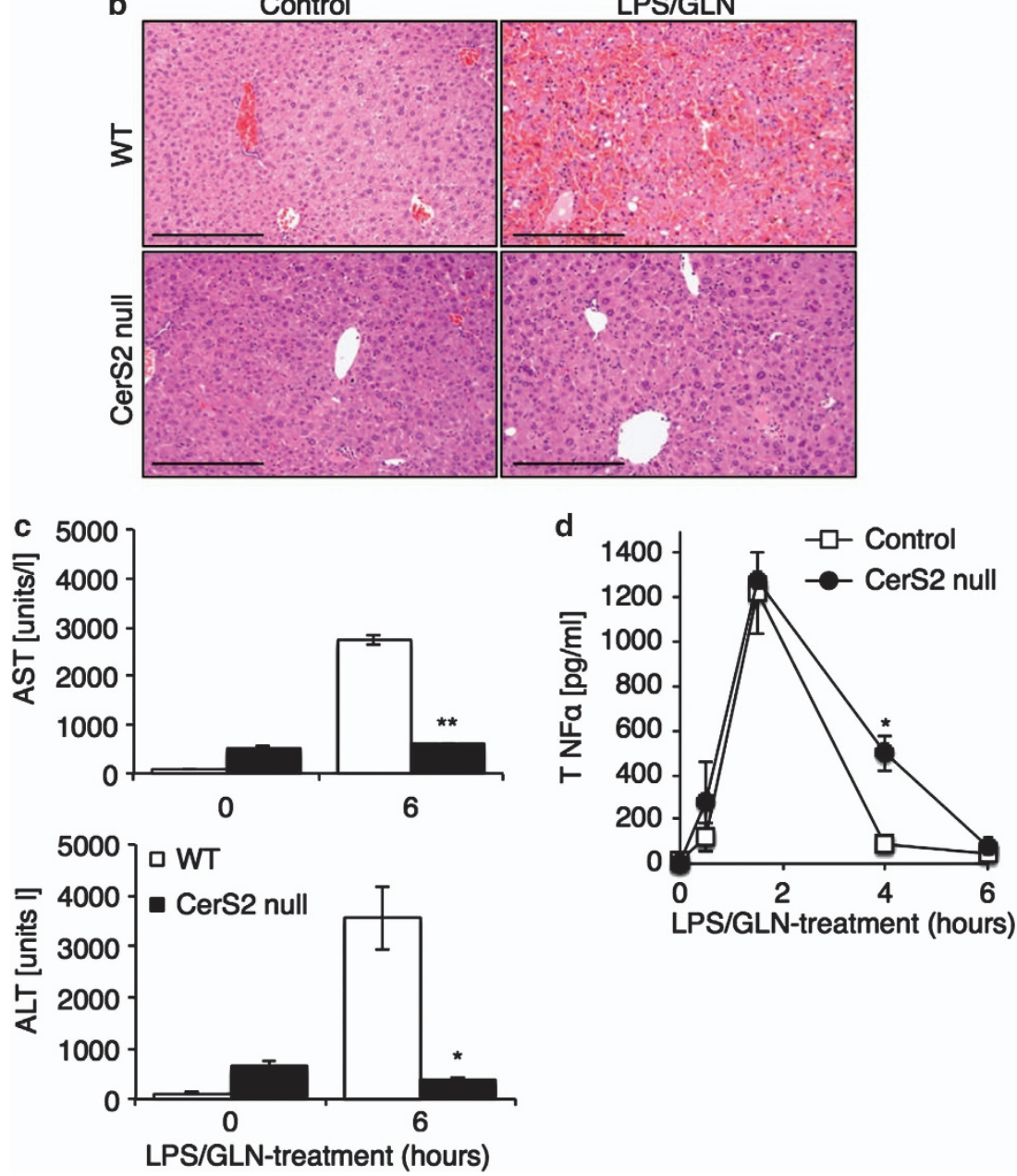

Figure 1 CerS2 null mice are resistant to fulminant hepatic failure. (a) Survival curve of WT and CerS2 null mice after injection with $15 \mu \mathrm{g} / \mathrm{kg} \mathrm{LPS} \mathrm{and} 800 \mathrm{mg} / \mathrm{kg} \mathrm{GLN}$. $n=14$ for WT, $n=7$ for CerS2 null mice. (b) H\&E staining $6 \mathrm{~h}$ after LPS/GLN injection. Scale bar $=100 \mu \mathrm{m}$. (c) Levels of ALT and AST in the serum $6 \mathrm{~h}$ after LPS/GLN injection. $n=3,{ }^{*} P<0.005 ;{ }^{* *} P<0.0005$. (d) Serum TNF $\alpha$ levels after injection of LPS/GLN. $n=3,{ }^{*} P<0.05$

were observed in TNFR1 mRNA (WT mouse, $0.78 \pm 0.53$ arbitrary units; CerS2 null, $1.2 \pm 0.4, n=5$ ) or protein levels in membranes from WT and CerS2 null mouse liver (Figure 6c). Similar to results in isolated hepatocytes, levels of RIP1 and TRAF2 were significantly reduced because of the activation of TNFR1 in WT but not in CerS2 null mouse liver (Figure 6d). RIP1 and TRAF2 levels were significantly elevated in CerS2 null mice (twofold for RIP1 and four-fold for TRAF2, Figure 6d). This could lead to sustained activation of $\mathrm{NF} \kappa \mathrm{B}$ in the non-treated CerS2 null mice. Therefore, we analyzed mRNA levels of a number of genes downstream to $\mathrm{NF}_{\kappa} \mathrm{B}$, and none of them were elevated (mRNA levels in arbitrary units: $\mathrm{Bcl}_{\mathrm{XL}}: 1.0 \pm 0.53$ (WT), $0.2 \pm 0.02$ (CerS2 null); XIAP: $1.0 \pm 0.2$ (WT), $0.6 \pm 0.1$ (CerS2 null); clAP2: $1 \pm 0.02$ (WT), $0.8 \pm 0.15$ (CerS2 null); A20: $1.0 \pm 0.6$ (WT), $1.2 \pm 0.3$ (CerS2 null)). Levels of 
a
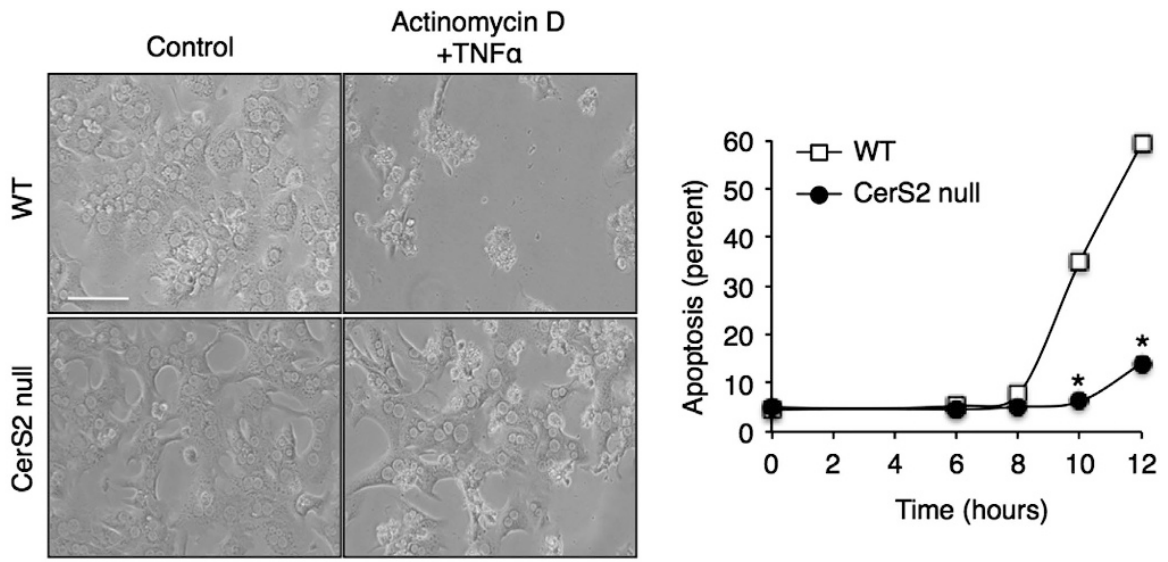

b

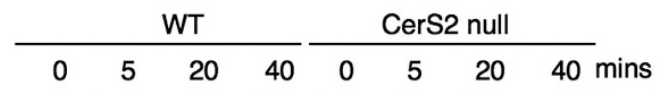

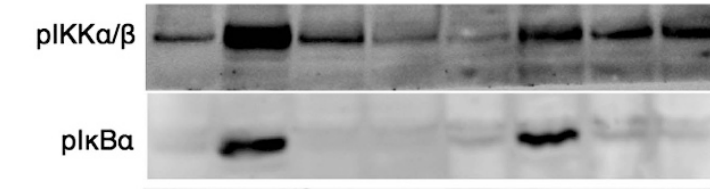

Total IkBa

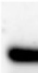

GAPDH
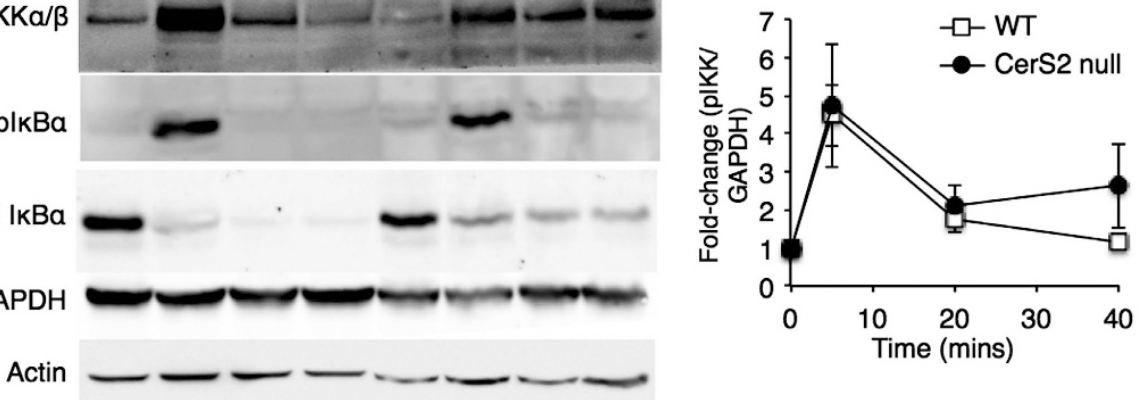

C

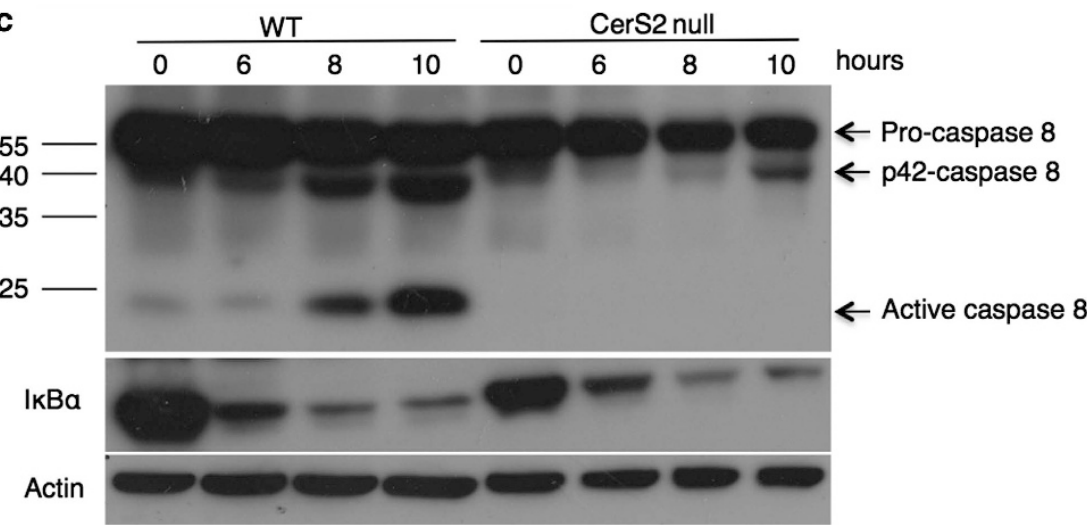

Figure 2 Activation of TNFR1 complex I signaling but not complex II signaling in cultured hepatocytes from CerS2 null mice. Cultured hepatocytes from WT and CerS2 null mice were treated with TNF $\alpha(100 \mathrm{ng} / \mathrm{ml})$ and ActD $(500 \mathrm{ng} / \mathrm{ml})$ for the indicated times. (a) Left-hand panels show representative phase contrast images of hepatocytes $12 \mathrm{~h}$ after treatment (scale bar $=100 \mu \mathrm{m}$ ) and the right-hand panel shows the extent of cell death (measured by LDH release). $n=3,{ }^{*} P<0.0005$. (b) The left-hand panel shows phosphorylation of IKK $\alpha / \beta$ and phosphorylation and degradation of $\mathrm{I}_{\kappa} \mathrm{B} \alpha$. Means \pm S.E.M. are shown in the right-hand panel, $n=3$. GAPDH and $\beta$-actin are shown as loading controls. (c) Pro-caspase 8 cleavage to its active $p 18$ form and $I_{\kappa} \mathrm{B} \alpha$ degradation. Results are from a typical experiment repeated three times. Mr markers are shown on the left, and the cleavage products indicated on the right. $\beta$-Actin is shown as a loading control

cFLIP $\mathrm{L}$ decreased after LPS/GLN treatment in WT but not in CerS2 null mice (Figure 6e).

Finally, we analyzed levels of aSMase activity after LPS/ GLN injection, as internalized TNFR1 forms receptosomes that fuse with trans-Golgi vesicles, resulting in activation of aSMase. ${ }^{7,25}$ aSMase activity was transiently activated in WT but not in CerS2 null mice (Figure 7), consistent with the lack of TNFR1 internalization.

\section{Discussion}

The main finding of the current study is that the acyl chain composition of SLs has a crucial role in regulating internalization of the TNFR1 and subsequent signaling for apoptosis in hepatocytes. CerS2 null mouse liver contains no VLC-SLs, but rather contains elevated levels of long chain (C16) SLs. ${ }^{15}$ As a result of these changes, significant alterations in the biophysical properties of liver membranes are observed, ${ }^{21}$ 
a

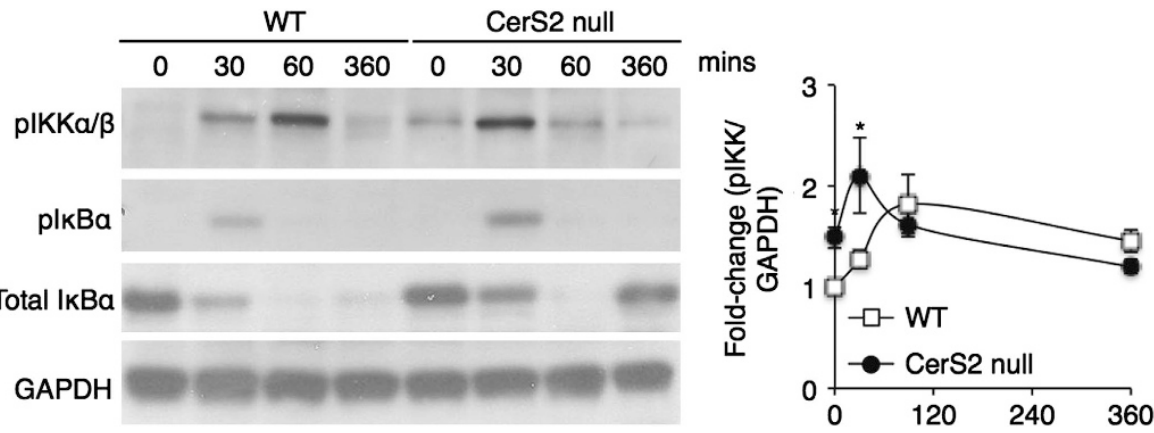

b

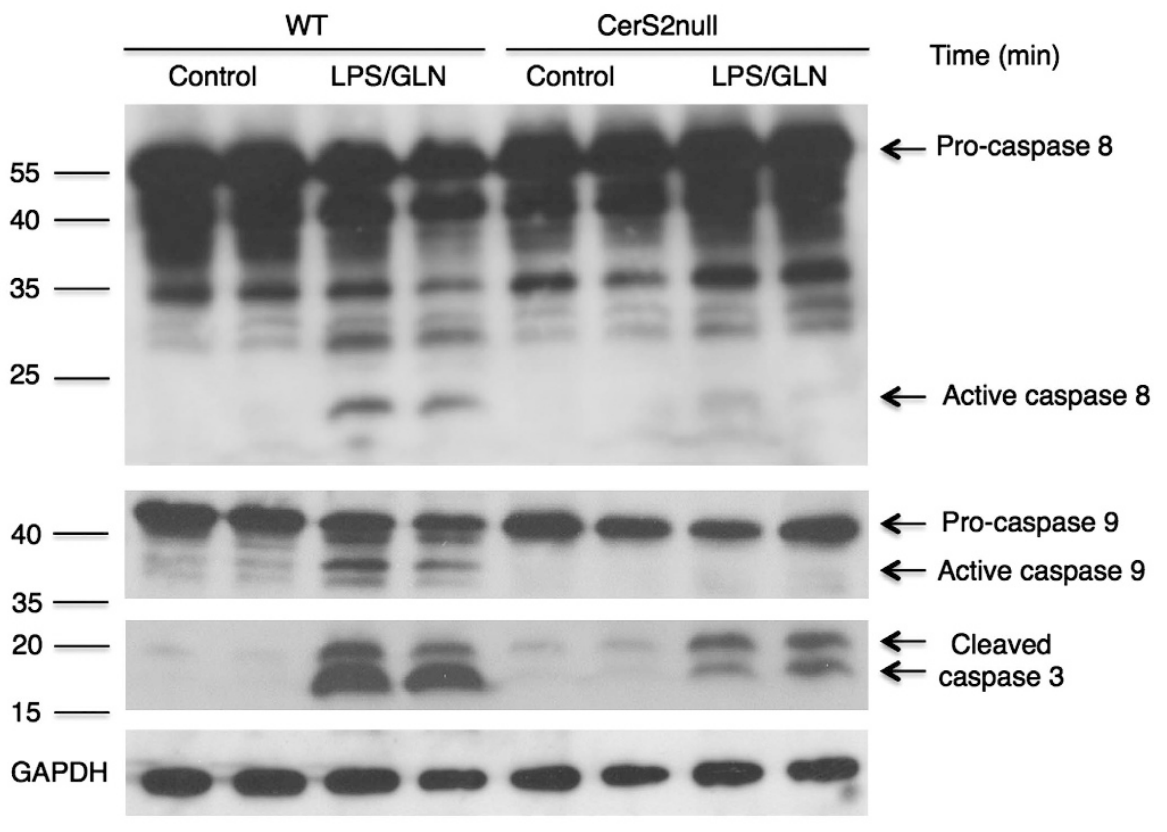

c
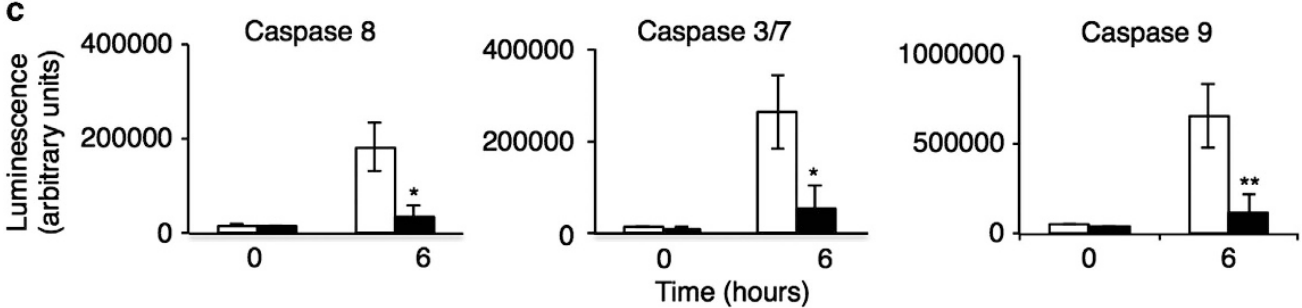

Figure 3 TNFR1 complex I signaling in LPS/GLN-treated CerS2 null mice. WT or CerS2 null mice were injected with $15 \mu \mathrm{g} / \mathrm{kg}$ LPS and $800 \mathrm{mg} / \mathrm{kg}$ GLN and various parameters measured at the indicated times. (a) The left-hand panel shows IKK $\alpha / \beta$ phosphorylation and $\mid \kappa B \alpha$ phosphorylation and degradation. Means \pm S.E.M. are shown in the right-hand panel, $n=3,{ }^{*} P<0.05$. GAPDH is shown as a loading control. (b) Western blot analysis of caspases 8,9 and 3 and their cleavage products $6 \mathrm{~h}$ after LPS/GLN injection. Mr markers are shown on the left, and the cleavage products indicated on the right. Results are from a typical experiment repeated five times, which gave similar results. (c) Activities of caspases $8,3 / 7$ and 9. Values are means \pm S.D., $n=5,{ }^{\star} P<0.005 ;{ }^{* \star} P<0.0005$

such as altered membrane fluidity and morphological alterations. Importantly, the localization of plasma membrane receptors to detergent-resistant membranes is also altered. For instance, translocation of the insulin receptor into detergent-resistant membranes and its subsequent phosphorylation is abrogated in CerS2 null mouse liver, resulting in hepatic insulin resistance. ${ }^{20}$ The current study on the inhibition of TNFR1 pro-apoptotic signaling is a further example of how altering the SL acyl chain composition affects membrane receptor function, but in this case, inhibition of receptor internalization appears to be due to modulation of a clathrin-mediated pathway ${ }^{6,25,26}$ rather than a lipid raft-mediated pathway. ${ }^{20}$ In contrast, TNFR1 complex I signaling is raft dependent ${ }^{3}$ but was not altered in the CerS2 null mouse, suggesting that altering the ratio between VLCand LC-ceramides specifically affects TNFR1 internalization but not its trimerization. However, TNFR1 activation was associated with prolonged $\mathrm{IKK} \alpha / \beta$ phosphorylation and slightly delayed $\mathrm{I} \kappa \mathrm{B} \alpha$ degradation, which could be due to attenuation of the internalization of the trimerized receptors, which might be vital for cessation of the $\mathrm{NF}_{\kappa} \mathrm{B}$ survival pathway. ${ }^{6}$ 


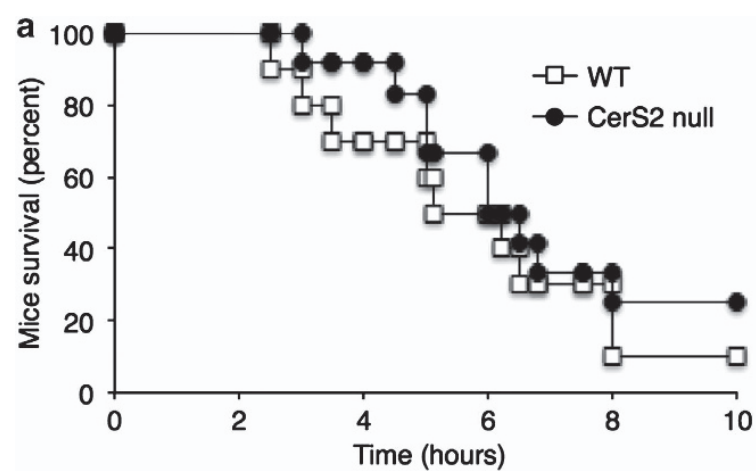

b
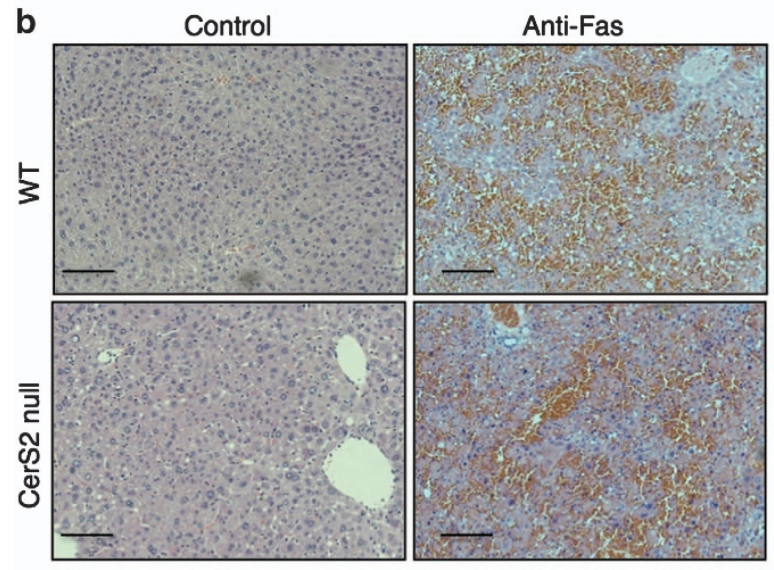

C Treatment None anti-Fas anti-Fas

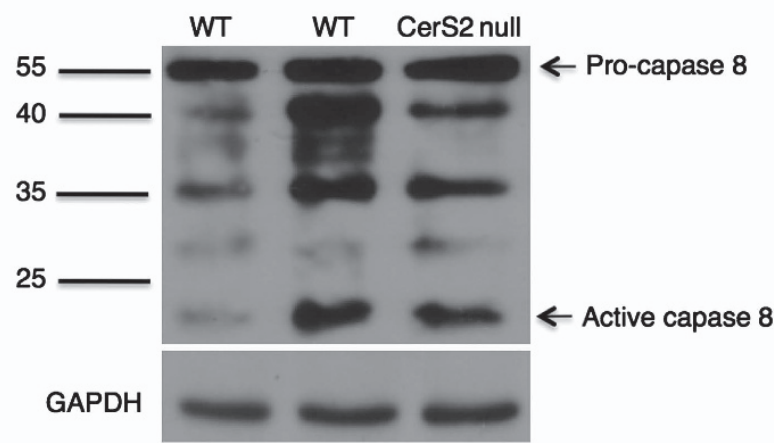

Figure 4 CerS2 null mice are not protected against Fas-mediated hepatitis. WT and CerS2 null mice were injected with $35 \mu \mathrm{g} / \mathrm{kg}$ of the Jo2 antibody for the indicated times. (a) Survival curve of WT and CerS2 null mice. $n=10$ for WT and $n=12$ for Cers2 null mice. (b) H\&E staining $6-8 \mathrm{~h}$ after injection with the Jo2 antibody. Scale bar $=100 \mu \mathrm{m}$. (c) Pro-caspase 8 cleavage to its active $\mathrm{p} 18$ form $6 \mathrm{~h}$ after injection. Results are from a typical experiment repeated four times. Mr markers are shown on the left, and the cleavage products indicated on the right. GAPDH is shown as a loading control

The mechanism of how clathrin-mediated internalization ${ }^{5,27}$ is affected by altering the ratio of SL acyl chain lengths is unknown, although it has been suggested that the stability of clathrin-coated pits is dependent on ceramide platforms. ${ }^{9,28,29}$ Thus, inclusion of LC-ceramides in giant unilamelar vesicles results in spontaneous membrane curvature and tubule formation, ${ }^{30}$ sphingomyelinase causes spontaneous vectorial membrane budding ${ }^{31}$ and ceramide triggers exosome budding and facilitates exosome secretion. ${ }^{32}$ Further, a B-cell membrane receptor, HM1.24, interacts with $\alpha$-adaptin in lipid rafts for internalization via clathrin. ${ }^{33,34}$ Together, inhibition of TNFR1 internalization in the CerS2 null mouse is consistent with the notion that clathrin-mediated pathways, in addition to raft-mediated pathways, can be regulated by SLs, perhaps by altering the recruitment of adaptor proteins required for clathrin-coated pit formation. ${ }^{33}$ In contrast, Fas receptor internalization is not required in hepatocytes (type II cells) in order to induce Fas-mediated cell death, demonstrating differential effects of altering the SL acyl chain length on different receptor-mediated pathways. ${ }^{5}$

It has been demonstrated that ceramide generation by aSMase or nSMase activation ${ }^{35-37}$ mediates stress-induced apoptosis including both caspase-dependent and -independent pathways. ${ }^{38-41}$ Upon trimerization, TNFR1 recruits nSMase to the cell membrane resulting in SM hydrolysis and enrichment of ceramide; ${ }^{4,5,42}$ subsequently, the internalized TNFR1 activates aSMase and de novo ceramide synthesis, with concomitant accumulation of C16-ceramide. ${ }^{13,43}$ Although CerS2 null mice accumulate high levels of C16-ceramide, no liver damage was observed following LPS/GLN treatment. This demonstrates that the apoptotic effects of $\mathrm{C} 16$-ceramide ${ }^{14}$ are downstream to generation of VLC-ceramides, consistent with the notion that the lack of TNF $\alpha$-mediated toxicity in CerS2 null mice is due to altered membrane properties, which impact upon TNFR1 endocytosis.

Importantly, inhibition of TNFR1 internalization in CerS2 null mice prevented activation of caspases 8,9 and 3 , of aSMase, cell death of hepatocytes and hepatitis. These results mirror previous observations on the critical role of TNFR1 internalization for recruitment of the death-inducing signaling complex or complex II proteins, TRADD, FADD and caspase 8 as well as aSMase, and the propagation of apoptosis in various cell systems. ${ }^{5,25}$ The inhibition of TNFR1 internalization by the adenoviral E3-protein 14,7K is instrumental for the immune escape mechanism of adenovirus infections. $^{25}$

TNFR1 internalization resulted in abrogation of RIP1 and TRAF2 degradation in CerS2 null mice. The lack of RIP1 and TRAF2 degradation was not due to altered proteasome activity. Unexpectedly, higher basal levels of TRAF2 and RIP1 were found in CerS2 null mice, which may be related to reduced basal levels of TNFR1 internalization. The ubiquitin protein ligase, CARP-2, which is a ubiquitin ligase of RIP1 upon TNFR1 internalization, was shown to act as a constitutive negative regulator of $\mathrm{TNF} \alpha$-induced $\mathrm{NF} \kappa \mathrm{B}$ activation. ${ }^{24}$ CARP-2 is localized in endocytic vesicles where it interacts with internalized TNF receptosomes and, together with A20, a ubiquitin ligase that ubiquitinates both TRAF2 and RIP1, ${ }^{44,45}$ mediates RIP1 ubiquitination and degradation. Although basal levels of RIP1 and TRAF2 were higher in CerS2 null mouse liver, genes downstream to $\mathrm{NF} \kappa \mathrm{B}$, such as A20, clAP2, $x I A P, B C L_{x L}$ and $I_{\kappa} B \alpha$, were not elevated in the CerS2 null mice, indicating that the elevated levels of RIP1 and TRAF2 do not contribute to the lack of sensitivity to FHF.

In summary, this study indicates the importance of VLC-SLs in TNFR1 signaling in hepatocytes. The ablation of VLC-SLs resulted in total inhibition of TNFR1 complex II signaling because of defective TNFR1 internalization. As different tissues contain different levels of SLs with different chain 

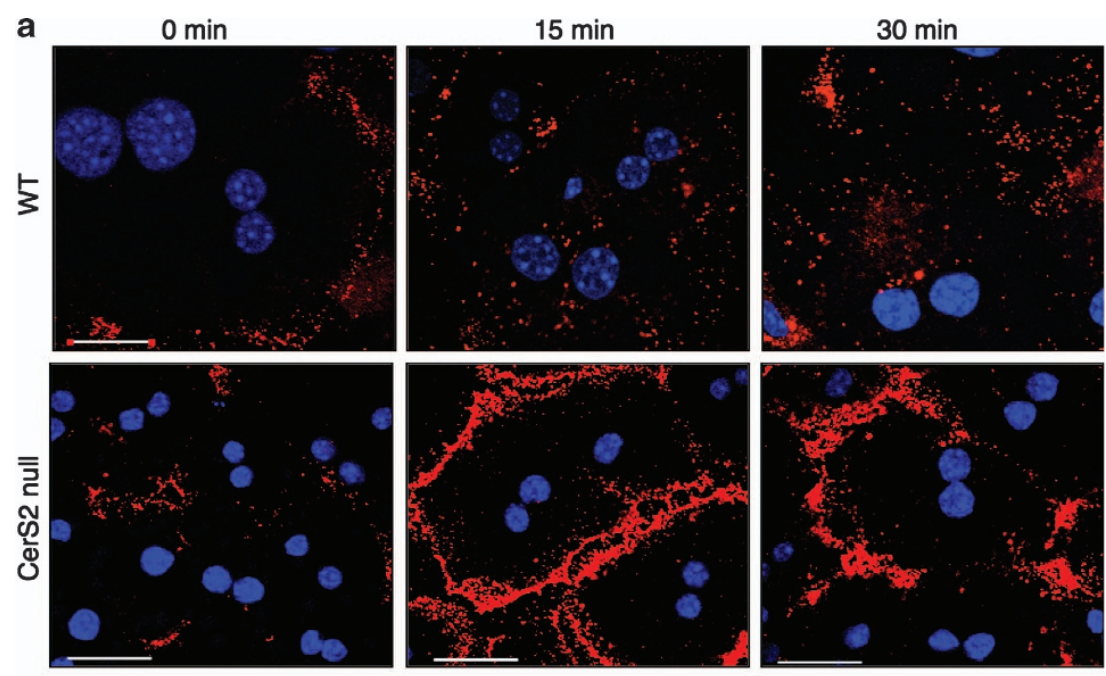

b

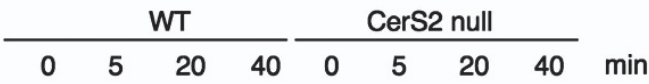

RIP1

TRAF2

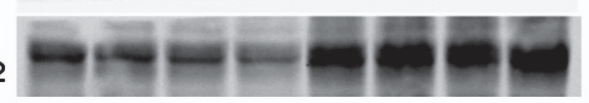

GAPDH
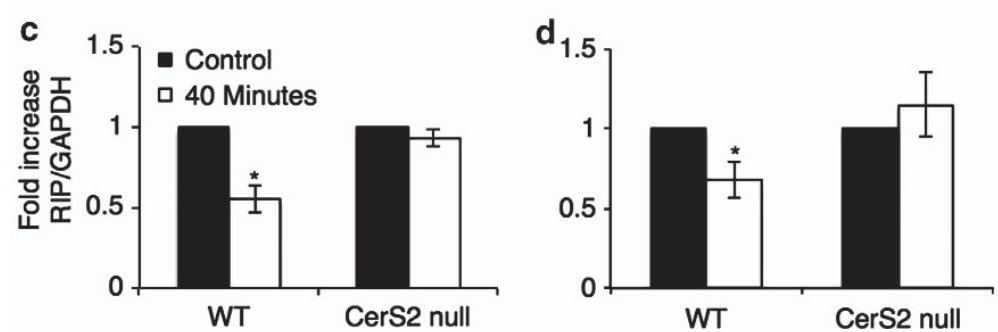

Figure 5 TNF $\alpha$ internalization is attenuated in cultured hepatocytes from CerS2 null mice. (a) Hepatocytes isolated from WT and CerS2 null mice were incubated with Fc-TNF $\alpha$ for 10 min on ice and subsequently incubated at $37^{\circ} \mathrm{C}$ for 15 and 30 min before examination by confocal microscopy. Blue indicates DAPI and red indicates Fc-TNF $\alpha$. Results are from a typical experiment repeated five times, which gave similar results. Scale bar $=20 \mu \mathrm{m}$. (b) Western blot analysis showing levels of RIP1 and TRAF2 in cultured hepatocytes at various times after TNF $\alpha(100 \mathrm{ng} / \mathrm{ml})$ and actinomycin D $(500 \mathrm{ng} / \mathrm{ml})$ treatment. GAPDH is shown as a loading control. Results are from a typical experiment repeated three times, which gave similar results. (c, d) Quantification of RIP1 (c) and TRAF2 (d) levels before (black columns) and 40 min after (open columns) TNF $\alpha$ /actinomycin D treatment; data are shown as fold-change of RIP1 and TRAF levels normalized to GAPDH. $n=3,{ }^{*} P<0.005$

lengths, ${ }^{46}$ our data suggest a novel means to regulate TNFR1 internalization, which may be of relevance for understanding why certain cancers display high resistance to TNF $\alpha$ mediated apoptosis. ${ }^{47-49}$

\section{Materials and Methods}

Antibodies and reagents. Antibodies were purchased from the following sources: anti-phospho-IKK $\alpha / \beta$, anti-phospho $I_{\kappa} \mathrm{B} \alpha$, anti-total $\mid \kappa \mathrm{B} \alpha$, anti-cleaved caspase 3, anti-caspase 9, anti-RIP, anti-TRAF2 and anti-FLIP (Cell Signaling, Boston, MA, USA); anti-caspase 8 (Alexis, Shoham, Israel); anti-TNFR1 (Abcam, Cambridge, UK); anti-Jo-2 agonistic anti-Fas antibody (BD Biosciences, San Jose, CA, USA); the anti $\mathrm{Na}^{+} / \mathrm{K}^{+}$ATPase antibody (Hybridoma $6 \mathrm{H}$ ) was a gift from Professor Haim Garty (Weizmann Institute, Rehovot, Israel). ${ }^{50}$ LPS, concanavalin $\mathrm{A}$ and $\mathrm{D}-(+)$-galactosamine hydrochloride were from Sigma-Aldrich (St Louis, MO, USA).

Animals. CerS2 null mice were generated and maintained as described. ${ }^{15}$ Mice were treated in accordance with the Animal Care Guidelines of the Weizmann
Institute of Science Animal Care Committee, and the National Institutes of Health's Guidelines for Animal Care.

Induction of FHF. Mice (10- to 12-week old) were injected intraperitoneally with $15 \mu \mathrm{g} / \mathrm{kg}$ LPS and $800 \mathrm{mg} / \mathrm{kg} \mathrm{GLN}$, or intravenously with $25 \mathrm{mg} / \mathrm{kg}$ concanavalin A, or with $35 \mu \mathrm{g} / \mathrm{kg}$ anti-Jo-2 agonistic anti-Fas antibody. Liver tissue sections were collected for histological examination or were flash frozen. Blood was collected via the orbital sinus and serum ALT and AST levels were analyzed using a Spotchem Strips system (Arkary, Edina, MN, USA). Serum cytokine levels were measured using an anti-mouse ELISA kit (BioLegend, San Diego, CA, USA). Caspase activity was measured using caspase-Glo 3/7, caspase-Glo 8 and caspase-Glo 9 activity kits (Promega, Madison, WI, USA), and aSMase activity was measured as described, ${ }^{15,51}$ with some modifications. Briefly, liver homogenates containing $40 \mu \mathrm{g}$ protein were incubated in a final volume of $500 \mu \mathrm{l}$ sodium acetate buffer ( $50 \mathrm{mM}$ sodium acetate $\mathrm{pH}$ 4.5). The reactions were started by addition of $4 \mu \mathrm{M} \mathrm{C}_{6}-\mathrm{NBD}$-sphingomyelin and incubated in the dark at $37^{\circ} \mathrm{C}$ for $15 \mathrm{~min}$. Reactions were terminated by addition of three volumes of chloroform/methanol $(1: 2 ; \mathrm{v} / \mathrm{v})$. Lipids were extracted and separated by thin-layer chromatography using chloroform/ 
a

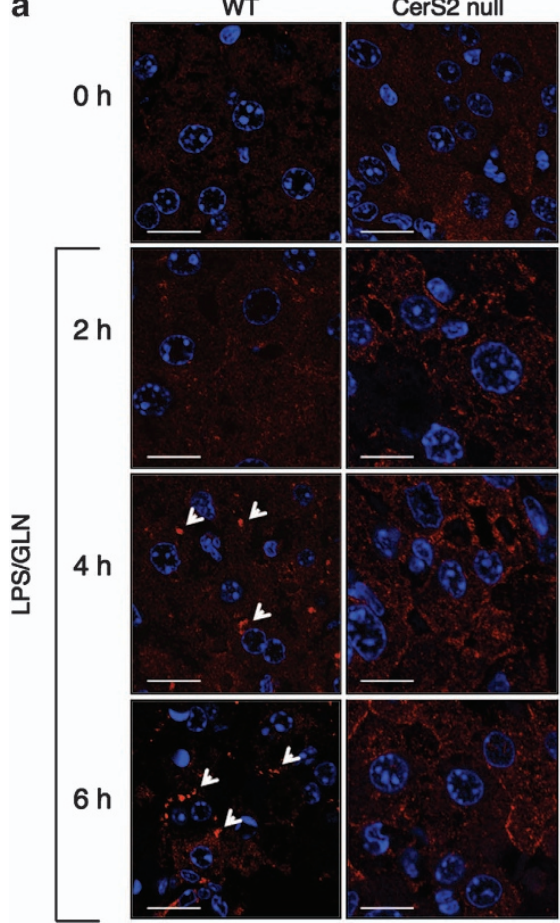

b
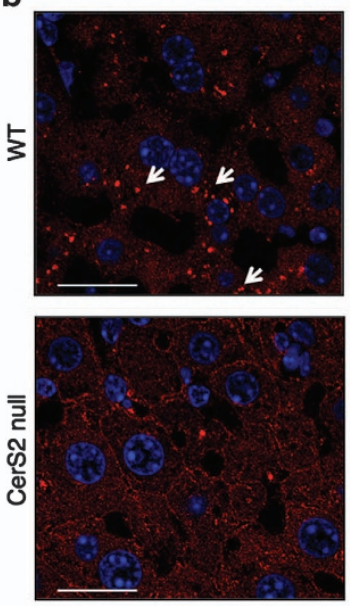

c WT Cers2 null

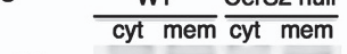

55 -

45

$\mathrm{Na}^{+} / \mathrm{K}^{+}$

ATPase

GAPDH
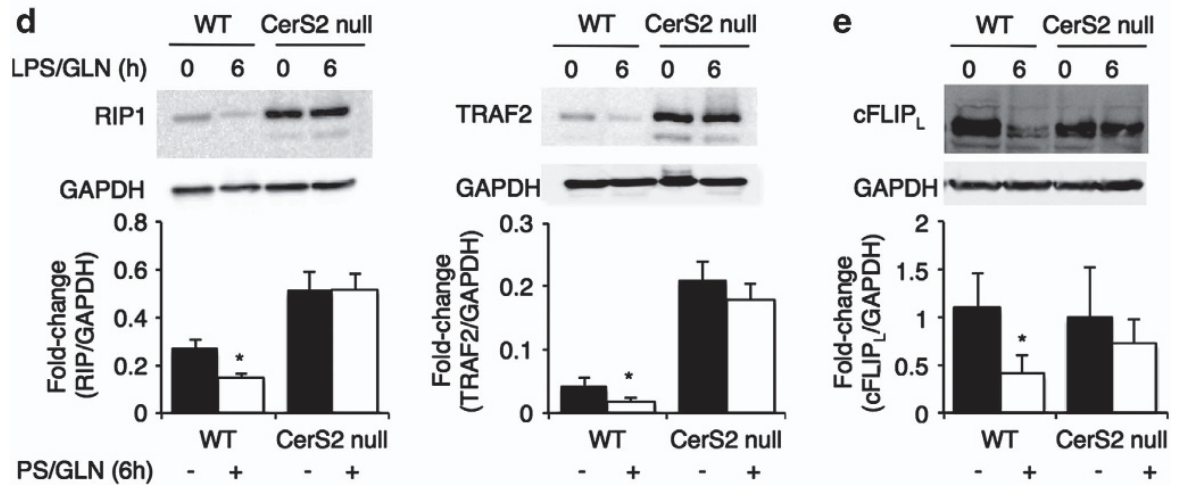

Figure 6 TNFR1 internalization is inhibited in CerS2 null mouse liver. (a) WT and CerS2 null mice were injected with $15 \mu \mathrm{g} / \mathrm{kg} \mathrm{LPS}$ and $800 \mathrm{mg} / \mathrm{kg}$ GLN for the indicated times. After isolation of livers, TNFR1 localization was determined by confocal microscopy. Blue indicates DAPI and red indicates TNFR1, highlighted in some cases by arrows. Results are from a typical experiment repeated three times. Scale bar $=10 \mu \mathrm{m}$. (b) WT and CerS2 null mice were injected with $25 \mathrm{mg} / \mathrm{kg}$ ConA for $8 \mathrm{~h}$ and TNFR1 localization determined by confocal microscopy. Arrows indicate internalized TNFR1. Results are from a typical experiment repeated three times. Scale bar $=20 \mu \mathrm{m}$. (c) Western blot analysis of TNFR1 in membrane $(\mathrm{mem})$ and cytosolic fractions (cyt) from CerS2 null and WT liver. Results are from a typical experiment repeated five times. The $\mathrm{Na}^{+} / \mathrm{K}^{+}$ ATPase was used as loading control for membrane fractions, *nonspecific band. GAPDH was used as loading control for cytoplasm fractions. (d) Levels of RIP1 (left-hand) and TRAF2 (right-hand) $6 \mathrm{~h}$ after LPS/GLN injection. Upper panels show typical western blots and the lower panels quantification for RIP1 $(n=8)$ and for TRAF2 $(n=6)$ normalized to GAPDH. ${ }^{*} P<0.05$. (e) $c F L I P L$ levels $6 \mathrm{~h}$ after $L P S / G L N$ injection. Upper panels show typical western blots and the lower panels quantification normalized to GAPDH. $n=6,{ }^{*} P<0.05$. For panels $\mathbf{d}$ and $\mathbf{e}$, black bars indicate untreated and open bars treated mice

methanol/9.8 $\mathrm{mM}$ aqueous $\mathrm{CaCl}_{2}(60: 35: 8 ; \mathrm{v} / \mathrm{v} / \mathrm{v})$ as the developing solvent. NBD-labeled SLs were identified using authentic standards by Fluor-S Max device (BioRad, Hercules, CA, USA) and quantified using Image Quant program (BioRad).

Western blotting. Cell or tissue lysates were prepared in radioimmuno-

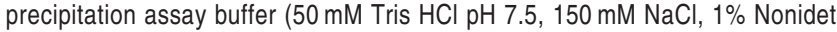
P- $40,0.5 \%$ sodium deoxycholate, $0.1 \%$ SDS) containing $50 \mathrm{mM} \mathrm{NaF}, 2 \mathrm{mM}$ $\mathrm{Na}_{3} \mathrm{VO}_{4}$, protease and phosphatase inhibitors (Sigma). Protein concentration was measured using the BCA Protein Assay Kit (Pierce Chemical Co., Rockford, IL, USA). Fifty $\mu \mathrm{g}$ of protein was loaded and separated on $8-15 \%$
SDS-PAGE and transferred to a nitrocellulose or PVDF membrane. The membrane was blocked using $5 \%$ bovine serum albumin (BSA) in phosphatebuffered saline containing $0.1 \%$ Tween-20 (PBST) for $1 \mathrm{~h}$ at room temperature. The primary antibody was diluted in PBST containing $1 \%$ BSA and incubated with the membrane at $4{ }^{\circ} \mathrm{C}$ overnight. After three washes with PBST, membranes were incubated with the secondary antibody in PBST containing $1 \% \mathrm{BSA}$ at room temperature for $1 \mathrm{~h}$.

Isolation of hepatocytes. Hepatocytes were isolated from mice after hepatic portal vein perfusion using warm $\mathrm{Ca}^{++}$- and $\mathrm{Mg}^{++}$-free Hank's balanced salt solution (Sigma-Aldrich) containing $5.5 \mathrm{mM} \mathrm{KCl}, 5.5 \mathrm{mM}$ glucose, 


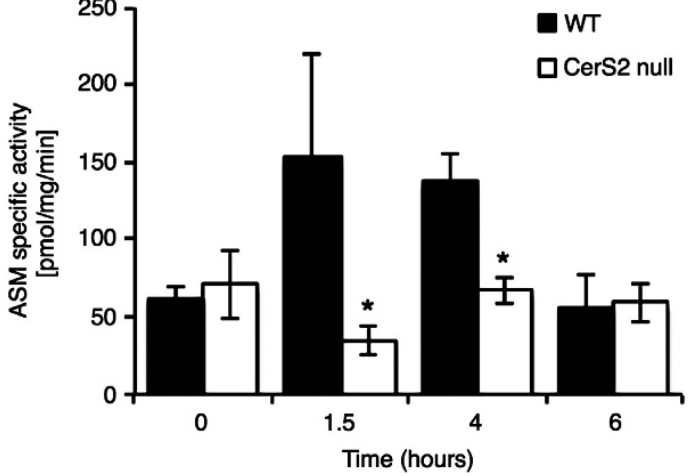

Figure 7 Lack of ASMase activation in CerS2 null mouse liver. WT and CerS2 null mouse were injected with $15 \mu \mathrm{g} / \mathrm{kg}$ LPS and $800 \mathrm{mg} / \mathrm{kg} \mathrm{GLN}$ and aSMase activity measured. Values are means \pm S.D. $n=3,{ }^{*} P<0.05$

$25 \mathrm{mM} \mathrm{NaHCO}$, $0.7 \mathrm{mM}$ EDTA for $3 \mathrm{~min}$, and liver digest media (GIBCO/BRL Life Technologies, Grand Island, NY, USA) for $8 \mathrm{~min}$. After perfusion, the liver was quickly excised and the gall bladder removed. Hepatocytes were separated from connective tissue using sterile tweezers and then passed through a cell strainer (BD Falcon Labware) and centrifuged at $50 \times g_{\mathrm{av}}\left(4^{\circ} \mathrm{C}, 5 \mathrm{~min}\right)$. Hepatocytes were suspended in DMEM containing $10 \%$ fetal bovine serum, $2 \mathrm{mM}$ sodium pyruvate, $2 \%$ penicillin/streptomycin and $1 \mu \mathrm{M}$ dexamethasone.

Fc-TNF $\alpha$ internalization. The Fc-TNF coding plasmid was provided by $\mathrm{H}$ Wajant (Julius-Maximilians University, Würzburg, Germany). The protein was transiently expressed in HEK cells and purified from the supernatant using HiTrap Protein G columns (GE Healthcare, Little Chalfont, UK). Hepatocytes were cultured on collagen-coated 13-mm glass coverslips and grown overnight. Cells were treated with $5 \mu \mathrm{g} / \mathrm{ml} \mathrm{Fc-TNF} \alpha$ on ice for $15 \mathrm{~min}$ and then washed twice with DMEM containing $1 \%$ BSA, 2 mM sodium pyruvate, $2 \%$ penicillin/streptomycin and $0.01 \mu \mathrm{M}$ dexamethasone to remove unbound Fc-TNF $\alpha$, and then transferred to $37^{\circ} \mathrm{C}$. In order to terminate FC-TNF $\alpha$ uptake, cells were washed three times with cold PBS and immediately fixed with $2 \%$ formaldehyde. Fc-TNF $\alpha$ was detected using a Cy3-conjugated anti-human IgG antibody before observation by confocal microscopy.

Histological analysis. Liver segments were fixed in $4 \%$ formaldehyde and embedded in paraffin for histological analysis. Sections $(5 \mu \mathrm{m})$ were stained with hematoxylin/eosin. For TNFR1 immunohistochemistry, sections were incubated at $4{ }^{\circ} \mathrm{C}$ overnight with primary antibody, and after antigen retrieval, incubated with a secondary antibody for $1 \mathrm{~h}$ at room temperature before counter staining with blue emissive Hoechst 33342 dye.

qPCR. Total RNA was isolated using the Rneasy mini kit (Qiagen, Venlo, Netherlands) according to manufacturer's instructions, which included a DNAse step and addition of $\beta$-mercaptoethanol. cDNA synthesis was performed using the Reverse-iT first strand synthesis kit (Thermo Scientific, Waltham, MA, USA) using random hexamers. cDNA products were stored at $-20^{\circ} \mathrm{C}$. qPCR was performed using the SYBR Green PCR Master Mix (Finnzyme, Vantaa, Finland) and an ABI Prism 7000 Sequence Detection System (Applied Biosystems, Grand Island, NY, USA) with CDNA (equivalent to $5 \mathrm{ng}$ of total RNA). The following primers were used:

I $\kappa \mathrm{B} \alpha:$ Forward: $5^{\prime}$-TTGGTCAGGTGAAGGGAGAC-3'; reverse: $5^{\prime}$-ACAGCCAAG TGGAGTGGAGT-3'.

TNFR1: Forward: 5'-GCCCCACCTCCGGCTTCAAC-3'; reverse: 5'-GTCAGGA CGTTGCGGGTGGG-3'

A20: Forward: 5'-GGTGATGGAAACTGCCTCAT-3'; reverse: 5'-CTTCCTCAGG ACCAGGTCAG

BCL ${ }_{X L}$ : Forward: GCTGGGACACTTTTGTGGAT-3'; reverse: 5'-AACCACACCA GCCACAGTC- $3^{\prime}$

CIAP2: Forward: 5'-CGAGGAGGAGGAGTCAGATG-3'; reverse: 5'-GGAGGCA ATACAGCATTGGT-3'.

XIAP: Forward: 5'-TTGGAACATGGACATCCTCA-3'; reverse: 5'-TACCACTTC GCATGCTGTTC-3'.
Confocal microscopy. Confocal microscopy was performed using an Olympus IX 81 Fluo-View 1000 microscope and a UPLSAPO $\times 60$ objective and images were processed and analyzed using FV-1000 software (Olympus, Tokyo, Japan).

Statistical analysis. Values are expressed as means \pm S.E.M. Statistical significance was calculated using the Student's t test.

\section{Conflict of Interest}

The authors declare no conflict of interest.

Acknowledgements. We thank Drs. David Wallach, Eli Arama and Atan Gross for helpful discussions, and Vladimir Kiss for help with confocal microscopy. This work was supported by the Israel Science Foundation (0888/11) (AHF) and by the Deutsche Forschungsgemeinschaft (DFG) Priority Program 877, Project B1 (SS). AH Futerman is the Joseph Meyerhoff Professor of Biochemistry at the Weizmann Institute of Science.

1. Cabal-Hierro L, Lazo PS. Signal transduction by tumor necrosis factor receptors. Cell Signal 2012; 24: 1297-1305.

2. Shuh M, Bohorquez $H$, Loss GE, Cohen AJ. Tumor necrosis factor- $\alpha$ : life and death of hepatocytes during liver ischemia/reperfusion injury. Ochsner J 2013; 13: 119-130.

3. Legler DF, Micheau O, Doucey M-A, Tschopp J, Bron C. Recruitment of TNF receptor 1 to lipid rafts is essential for TNF $\alpha$-mediated NF-KB activation. Immunity 2003; 18: $655-664$

4. Schneider-Brachert W, Tchikov V, Neumeyer J, Jakob M, Winoto-Morbach S, Held-Feindt J et al. Compartmentalization of TNF receptor 1 signaling: internalized TNF receptosomes as death signaling vesicles. Immunity 2004; 21 : 415-428.

5. Schütze S, Tchikov V, Schneider-Brachert W. Regulation of TNFR1 and CD95 signalling by receptor compartmentalization. Nat Rev Mol Cell Biol 2008; 9: 655-662.

6. Schütze S, Schneider-Brachert W. Results and Problems in Cell Differentiation, Vol 49. Springer: Berlin Heidelberg, 2009. pp 63-85.

7. Edelmann BAR, Bertsch U, Tchikov V, Winoto-Morbach S, Perrotta C, Jakob M et al. Caspase-8 and caspase-7 sequentially mediate proteolytic activation of acid sphingomyelinase in TNF-R1 receptosomes. EMBO J 2010; 30: 379-394.

8. Heinrich M, Neumeyer J, Jakob M, Hallas C, Tchikov V, Winoto-Morbach S et al. Cathepsin $D$ links TNF-induced acid sphingomyelinase to Bid-mediated caspase- 9 and -3 activation. Cell Death Differ 2004; 11: 550-563.

9. Gulbins E, Grassmé H. Ceramide and cell death receptor clustering. Biochim Biophys Acta 2002; 1585: 139-145.

10. Verheij M, Bose R, Lin XH, Yao B, Jarvis WD, Grant S et al. Requirement for ceramideinitiated SAPK/JNK signalling in stress-induced apoptosis. Nature 1996; 380: 75-79.

11. Milhas D, Clarke CJ, Hannun YA. Sphingomyelin metabolism at the plasma membrane: implications for bioactive sphingolipids. FEBS Lett 2010; 584: 1887-1894.

12. Patti GJ, Yanes O, Shriver LP, Courade JP, Tautenhahn R, Manchester M et al. Metabolomics implicates altered sphingolipids in chronic pain of neuropathic origin. Nat Chem Biol 2012; 8: 232-234.

13. García-Ruiz C, Colell A, Marí M, Morales A, Calvo M, Enrich C et al. Defective TNF-alphamediated hepatocellular apoptosis and liver damage in acidic sphingomyelinase knockout mice. J Clin Invest 2003; 111: 197-208.

14. Osawa Y, Uchinami H, Bielawski J, Schwabe RF, Hannun YA, Brenner DA. Roles for C16-ceramide and sphingosine 1-phosphate in regulating hepatocyte apoptosis in response to tumor necrosis factor-alpha. J Biol Chem 2005; 280: 27879-27887.

15. Pewzner-Jung Y, Park H, Laviad EL, Silva LC, Lahiri S, Stiban J et al. A critical role for ceramide synthase 2 in liver homeostasis: I. alterations in lipid metabolic pathways. J Biol Chem 2010; 285: 10902-10910.

16. Pewzner-Jung Y, Brenner O, Braun S, Laviad EL, Ben-Dor S, Feldmesser E et al. A critical role for ceramide synthase 2 in liver homeostasis: II. insights into molecular changes leading to hepatopathy. J Biol Chem 2010; 285: 10911-10923.

17. Laviad EL, Albee L, Pankova-Kholmyansky I, Epstein S, Park H, Merrill AH Jr et al. Characterization of ceramide synthase 2 : tissue distribution, substrate specificity, and inhibition by sphingosine 1-phosphate. J Biol Chem 2008; 283: 5677-5684.

18. Pewzner-Jung $\mathrm{Y}$, Ben-Dor S, Futerman $\mathrm{AH}$. When do Lasses (longevity assurance genes) become CerS (ceramide synthases)?: Insights into the regulation of ceramide synthesis. J Biol Chem 2006; 281: 25001-25005.

19. Zigdon H, Kogot-Levin A, Park JW, Goldschmidt R, Kelly S, Merrill AH Jr et al. Ablation of ceramide synthase 2 causes chronic oxidative stress due to disruption of the mitochondrial respiratory chain. J Biol Chem 2013; 288: 4947-4956.

20. Park J-W, Park WJ, Kuperman Y, Boura-Halfon S, Pewzner-Jung Y, Futerman AH. Ablation of very long acyl chain sphingolipids causes hepatic insulin resistance in mice due to altered detergent-resistant membranes. Hepatology 2013; 57: 525-532. 
21. Silva LC, Ben David O, Pewzner-Jung Y, Laviad EL, Stiban J, Bandyopadhyay S et al. Ablation of ceramide synthase 2 strongly affects biophysical properties of membranes. J Lipid Res 2012; 53: 430-436.

22. Lehmann V, Freudenberg MA, Galanos C. Lethal toxicity of lipopolysaccharide and tumor necrosis factor in normal and D-galactosamine-treated mice. J Exp Med 1987; 165: 657-663.

23. Leist M, Gantner F, Bohlinger I, Germann PG, Tiegs G. Wendel A. Murine hepatocyte apoptosis induced in vitro and in vivo by TNF-alpha requires transcriptional arrest. J Immunol 1994; 153: 1778-1788.

24. Liao W, Xiao Q, Tchikov V, Fujita K, Yang W, Wincovitch S et al. CARP-2 is an endosomeassociated ubiquitin ligase for RIP and regulates TNF-induced NF-kappaB activation. Curr Biol 2008; 18: 641-649.

25. Schneider-Brachert W, Tchikov V, Merkel O, Jakob M, Hallas C, Kruse ML et al. Inhibition of TNF receptor 1 internalization by adenovirus $14.7 \mathrm{~K}$ as a novel immune escape mechanism. J Clin Invest 2006; 116: 2901-2913.

26. Mosselmans R, Hepburn A, Dumont JE, Fiers W, Galand P. Endocytic pathway of recombinant murine tumor necrosis factor in L-929 cells. J Immunol 1988; 141: 3096-3100.

27. Cheng Z-J, Singh RD, Sharma DK, Holicky EL, Hanada K, Marks DL et al. Distinct mechanisms of clathrin-independent endocytosis have unique sphingolipid requirements. Mol Biol Cell 2006; 17: 3197-3210.

28. Grassmé H, Riethmüller J, Gulbins E. Biological aspects of ceramide-enriched membrane domains. Prog Lipid Res 2007; 46: 161-170.

29. Gulbins E, Kolesnick R. Raft ceramide in molecular medicine. Oncogene 2003; 22 7070-7077.

30. Varela ARP, Gonçalves da Silva AM, Fedorov A, Futerman AH, Prieto M, Silva LC. Effect of glucosylceramide on the biophysical properties of fluid membranes. Biochim Biophys Acta 2013; 1828: 1122-1130.

31. Holopainen JM, Angelova MI, Kinnunen PKJ. Vectorial budding of vesicles by asymmetrical enzymatic formation of ceramide in giant liposomes. Biophys $\mathrm{J} 2000 ; 78$ : 830-838.

32. Trajkovic K, Hsu C, Chiantia S, Rajendran L, Wenzel D, Wieland F et al. Ceramide triggers budding of exosome vesicles into multivesicular endosomes. Science 2008; 319: 1244-1247.

33. Rollason R, Korolchuk V, Hamilton C, Schu P, Banting G. Clathrin-mediated endocytosis of a lipid-raft-associated protein is mediated through a dual tyrosine motif. J Cell Sci 2007; 120: $3850-3858$

34. Masuyama N, Kuronita T, Tanaka R, Muto T, Hirota Y, Takigawa A et al. HM1.24 is internalized from lipid rafts by clathrin-mediated endocytosis through interaction with alpha-adaptin. J Biol Chem 2009; 284: 15927-15941.

35. Smith EL, Schuchman EH. Acid sphingomyelinase overexpression enhances the antineoplastic effects of irradiation in vitro and in vivo. Mol Ther 2008; 16: 1565-1571.

36. Smith EL, Schuchman EH. The unexpected role of acid sphingomyelinase in cell death and the pathophysiology of common diseases. FASEB J 2008; 22: 3419-3431.

37. Zeidan YH, Hannun YA. The acid sphingomyelinase/ceramide pathway: biomedical significance and mechanisms of regulation. Curr Mol Med 2010; 10: 454-466.
38. Carpinteiro A, Dumitru C, Schenck M, Gulbins E. Ceramide-induced cell death in malignant cells. Cancer Lett 2008; 264: 1-10.

39. Neumeyer J, Hallas C, Merkel O, Winoto-Morbach S, Jakob M, Thon L et al. TNF-receptor I defective in internalization allows for cell death through activation of neutral sphingomyelinase. Exp Cell Res 2006; 312: 2142-2153.

40. Daido S, Kanzawa T, Yamamoto A, Takeuchi H, Kondo Y, Kondo S. Pivotal role of the cell death factor BNIP3 in ceramide-induced autophagic cell death in malignant glioma cells. Cancer Res 2004; 64: 4286-4293.

41. Thon L, Möhlig H, Mathieu S, Lange A, Bulanova E, Winoto-Morbach S et al. Ceramide mediates caspase-independent programmed cell death. FASEB J 2005; 19: 1945-1956.

42. Philipp S, Puchert M, Adam-Klages S, Tchikov V, Winoto-Morbach S, Mathieu S et a. The polycomb group protein EED couples TNF receptor 1 to neutral sphingomyelinase. Proc Natl Acad Sci USA 2010; 107: 1112-1117.

43. Ullio C, Casas J, Brunk UT, Sala G, Fabriàs G, Ghidoni R et al. Sphingosine mediates TNF $\alpha$-induced lysosomal membrane permeabilization and ensuing programmed cell death in hepatoma cells. J Lipid Res 2012; 53: 1134-1143.

44. Wertz IE, O'Rourke KM, Zhou H, Eby M, Aravind L, Seshagiri S et al. De-ubiquitination and ubiquitin ligase domains of A20 downregulate NF- $\mathrm{KB}$ signalling. Nature 2004; 430: 694-699.

45. Boone DL, Turer EE, Lee EG, Ahmad RC, Wheeler MT, Tsui $C$ et al. The ubiquitinmodifying enzyme A20 is required for termination of Toll-like receptor responses. Nat Immunol 2004; 5: 1052-1060.

46. Levy M, Futerman AH. Mammalian ceramide synthases. IUBMB life 2010; 62: 347-356.

47. Burow ME, Weldon CB, Tang Y, Navar GL, Krajewski S, Reed JC et al. Differences in susceptibility to tumor necrosis factor alpha-induced apoptosis among MCF-7 breast cancer cell variants. Cancer Res 1998; 58: 4940-4946.

48. Donato NJ, Klostergaard J. Distinct stress and cell destruction pathways are engaged by TNF and ceramide during apoptosis of MCF-7 cells. Exp Cell Res 2004; 294 523-533.

49. Hannun YA, Obeid LM. Many ceramides. J Biol Chem 2011; 286: 27855-27862.

50. Moshitzky S, Asher C, Garty H. Intracellular trafficking of FXYD1 (phospholemman) and FXYD7 proteins in Xenopus oocytes and mammalian cells. J Biol Chem 2012; 287: 21130-21141.

51. Halasiddappa LM, Koefeler H, Futerman AH, Hermetter A. Oxidized phospholipids induce ceramide accumulation in RAW 264.7 macrophages: role of ceramide synthases. PLOS ONE 2013; 8: e70002.

(i) $(-)$ Cell Death and Disease is an open-access journal published by Nature Publishing Group. This work is licensed under a Creative Commons Attribution-NonCommercialNoDerivs 3.0 Unported License. To view a copy of this license, visit http://creativecommons.org/licenses/by-nc-nd/3.0/ 